\title{
Australian Unemployment in the Long Run, 1903-2007
}

\author{
By \\ Sambit Bhattacharyya \\ (Australian National University) \\ and \\ Timothy J. Hatton \\ (Australian National University and University of Essex)
}

March 2010

\begin{abstract}
We develop a two equation model of wage setting and unemployment, which we estimate on annual time series for Australia since Federation. Our model links the real wage level to productivity and to a set of wage pressure variables, while the unemployment rate is linked to the gap between the real wage and productivity and to demand side variables. We evaluate the contribution of different variables to the equilibrium unemployment rate for 1903-41, 1942-73 and 1974-2007. We also examine the effects on unemployment of several key policy-related episodes in wage regulation spread over the past century of labour market history.
\end{abstract}

\section{Acknowledgements}

We are grateful for useful comments from participants at the workshop on "Australian Riches: A Case Study in Economic Success" at the University of Melbourne, July $31^{\text {st }}$ August $1^{\text {st }}$ 2009. We also thank Jeff Borland, Jeff Sheen and two anonymous referees for their valuable comments. 


\section{Introduction}

In this paper we examine the determinants of the unemployment rate in Australia since Federation. This provides a richer basis on which to examine the fundamental forces that drive unemployment than analyses that focus only on the period since about 1970. Our aim is to account for the main determinants of real wages and unemployment in a dynamic model that captures the key features in the century-long evolution of the aggregate labour market. We use the model to estimate the equilibrium unemployment rate for major periods of labour market history and to conduct policy simulations

As Figure 1 shows, there are sharp differences in the level and volatility of the unemployment rate across the decades of the twentieth century. From Federation in 1901 to 1929 the unemployment rate averaged around five percent, with some significant ups and downs. The Great Depression of the 1930s witnessed a dramatic rise in the unemployment, peaking at nearly 20 percent, and this was followed by an equally dramatic fall from the mid1930s to the middle of the Second World War. The period from 1942 to the early 1970s saw unemployment rates that were relatively low and stable, falling below two percent during the immediate postwar period and again in the late 1960s. From the early 1970s unemployment drifted upwards with sharp peaks in the early 1980s and the early 1990s. Since 1993 the trend has been downwards until by 2006 the unemployment rate dipped below 5 percent, a level last seen in the mid-1970s.

A large literature has sought to identify the Non-Accelerating Inflation Rate of Unemployment (NAIRU) using different versions of the augmented Phillips curve framework that originated with Friedman and Phelps in the late 1960s. Gruen et al. (1999) provide an excellent survey of this literature up to the late 1990s, charting its evolution and its links with monetary policy (see also Borland and McDonald, 2000). Most of the work uses quarterly data and focuses on the period since the 1960s and it therefore misses the longer run diversity in the Australia's unemployment experience.

The Phillips curve literature for Australia has focused on a number of closely related issues. The first addresses a long-standing debate over whether changes in centralised wage setting policies have shifted the Phillips curve (see for example Gregory 1986; Pissarides, 1991; Watts and Mitchell, 1990; Wooden, 2001; Lye and McDonald, 2004). A second theme is to try and identify the effect of labour market variables such as unemployment benefit rates, tax wedges and structural change on the NAIRU (for example Pissarides, 1991; Groenewald and Hagger, 1998). A third focus is to track changes in the NAIRU by directly estimating a time-varying NAIRU or by allowing for regime shifts in the Phillips curve 
(Debelle and Vickery, 1998b; Gruen et al., 1999; Lye and McDonald, 2006; Kennedy et al., 2008; Lim et al., 2009).

While most have followed the standard Phillips curve approach, a few papers have invoked the framework of Layard et al (2005), estimating a wage setting equation in levels and then using another equation for unemployment as a function of the wage (a labour demand equation) to determine the equilibrium unemployment rate. Examples of this approach include Pissarides (1991) and Debelle and Vickery (1998a) as well as Dimsdale and Horsewood (2002), who focus on the interwar period. Our model is closer to these but it nests alternative approaches as special cases.

To some degree the focus of research has been to explain the upward trend in unemployment from the late 1960s to the late 1990s. But over the whole century there have been upward and downward trends and decades of high and low unemployment. The challenge in this paper is to explain the long-term evolution of unemployment in a consistent framework. In the next section we lay out the model and examine some of its properties. We then outline the evolution of the centralised wage setting system and show how this is consistent with our theoretical framework, and we examine some of the key variables that determine unemployment in the long run. Having discussed the data, we present econometric estimates for real wages and unemployment over the 105 years from 1903 to 2007 . We use the model to estimate an equilibrium unemployment rate in three periods, 1903-41, 1942-73 and 1974-2007, looking for the effects of changing economic structure and institutions on the equilibrium unemployment rate. Finally we use simulations to examine the unemployment effects of several well-known episodes in wage regulation over the past century of labour market history. Our findings are summarised in a short conclusion.

\section{The Model}

Here we develop a model of wage setting and unemployment that generates a steady state unemployment rate and that differs from the traditional Philips curve approach. We argue that this framework is more appropriate for long run analysis of annual data. It puts labour productivity at centre stage and it stresses adjustment to 'disequilibrium' deviations between the real wage and productivity.

The real wage is determined as the outcome of bargaining between workers and employers. Much of the literature adopts a new Keynesian framework in which there are matching frictions and the wage is determined as the outcome of a Nash bargain. Here the bargained wage depends on labour productivity, workers' bargaining power and the outside 
opportunity or threat points. The real wage outcome, with all variables in natural logs, may be approximated as: ${ }^{1}$

$(w-p)^{*}=q+\gamma+v$

Where $w-p$ is the real wage, $q$ is labour productivity, $\gamma$ reflects workers' bargaining strength and $v$ is a function of variables representing the outside option relative to the bargained wage (reflected for example in the replacement rate). Recent studies have found that, when calibrated to the data, the underlying matching models fail to capture the magnitude of fluctuations in unemployment, and that productivity shocks are almost entirely absorbed by wage adjustments (Shimer, 2005). But as Hall (2005) points out there is a range of feasible wage outcomes between the threat points, so that some divergence is possible between the real wage and productivity. Hall (2005) and Blanchard and Gali (2008) therefore build an element of wage rigidity in response to productivity shocks. Sticky wage adjustment may be interpreted as slowly adjusting wage norms or social consensus that would be characteristic of centralised wage setting.

Following Hall (2005, p. 64), we introduce wage rigidity in the form of partial adjustment where

$\Delta(w-p)_{t}=\varphi\left[(w-p)_{t}^{*}-(w-p)_{t-1}\right]$

Our estimating equation is written, with all variables in logs as:

$\Delta(w-p)_{t}=\beta_{0}+\beta_{1} \Delta q_{t}-\beta_{2}\left[(w-p)_{t-1}-q_{t-1}\right]-\beta_{3} u_{t-1}+x_{t}$

Where the parameters, $\beta$, are positive. $u$ is the unemployment rate; higher unemployment weakens the bargaining power of labour and reduces the bargained wage (thus: $-\beta_{3} u_{t-1}=\varphi \gamma$ ). This may also include trade union strength and other wage pressure variables of the sort invoked and explored at length by Layard et al. (2005). $x$ is the outside option relative to the bargained wage $\left(x_{t}=\varphi v\right)$; this could be unemployment benefits or other sources of outside income.

As a result of partial adjustment, the model includes an error correction term so that the real wage adjusts towards productivity, with the elasticity restricted to unity in the long run. For $0<\beta_{2}<1$, the real wage follows a geometric lag of past values of its determinants;

\footnotetext{
${ }^{1}$ The lagrangean for the Nash bargain in $\log$ form is: $L=(1-\gamma) \ln (\Pi)+\gamma \ln (W-V)+\lambda(Q-\Pi-W)$, where $\prod$ is the firm's profit from the match, $W$ is the (real) wage, $V$ is the worker's outside option, $Q$ is the worker's productivity, and $\gamma$ is the worker's bargaining power. From the first order conditions we obtain the bargained wage as: $W^{*}=\gamma Q+(1-\gamma) V$. Rearranging: $W^{*}=Q+\frac{1-\gamma}{\gamma}\left(V-W^{*}\right)$. The equation in the text is a log-linearised approximation to this, where $v$ is interpreted as the outside option relative to the bargained wage.
} 
the smaller is $\beta_{2}$ the longer are the lags. This gives a relationship in levels between the real wage and its determinants. For $\beta_{1}=\beta_{2}=1$, the real wage is simply a markup on productivity (in the short-run and the long run) that depends on unemployment and the wage pressure variables. For $\beta_{2}=0$, the model represents a real wage Phillips curve and there is no long run relationship in levels between the real wage and its determinants. There has been some debate in the literature about wage curves versus Phillips curves (Blanchard and Katz, 1997; Bell et al. 2002). For Australia, Gruen et al. (1999, p. 227) find no evidence that an error correction term works in a Phillips curve for price inflation estimated on quarterly data. ${ }^{2}$

There are two particular aspects of the model to note. The first is that the log of the unemployment rate is lagged one period, supporting the interpretation that this is a wage setting function, with causality running from higher unemployment to lower real wages. Thus in the long run, the real wage deflated by productivity is negatively related to the unemployment rate and is positively related to the wage pressure variables. These may also include variables such as the ratio of consumer to producer prices and taxes on earningsvariables that drive a wedge between the real wage faced by employers and that received by workers. The second is that productivity plays a prominent role, something that is largely overlooked in the framework of Layard et al. (Blanchard, 2007). In some Phillips curve specifications productivity is included by taking the dependent variable as unit labour costs (e.g. Gruen et al., 1999, p. 230), thus imposing the restrictions $\beta_{1}=1, \beta_{2}=0$.

If there is a long run levels relationship between the real wage and the unemployment rate then, in contrast to the traditional Phillips curve approach, wage setting alone does not produce an equilibrium unemployment rate. Thus, the second equation characterises the relationship between the unemployment rate and the real wage, which is essentially a dynamic labour demand equation, as in Manning (1993). In the long run we have:

$u^{*}=(\delta(w-p-q)-y)$

Where the first term is the productivity-adjusted real wage and $y$ is a set of labour demand shift variables. The partial adjustment process is:

$\Delta u_{t}=\theta\left(u_{t}^{*}-u_{t-1}\right)$

Our empirical specification is written as:

$u_{t}=\alpha_{0}+\alpha_{1} u_{t-1}-\alpha_{2} \Delta q_{t}+\alpha_{3}[(w-p)-q]_{t-1}-z_{t}$

Where the parameters $\alpha$ are positive and $z$ includes labour demand shift variables, $y$, as well as a stochastic term.

\footnotetext{
${ }^{2}$ However, Kennedy and Borland (2000) find evidence for a wage curve on micro-level data for Australia.
} 
Here we include the real wage only with a lag to emphasize that causality runs from the real wage to unemployment. Thus unemployment adjusts to the 'disequilibrium' gap between productivity and the real wage, which is eroded over time by the effects of unemployment in the wage setting equation. One key test of the model interpretation is that unemployment and the real wage (adjusted by productivity) are negatively related in wage adjustment equation and positively related in the unemployment equation. $z$ includes variables such as the interest rate that, in the matching framework, influence the present value of vacancy. It also includes the relevant wedge terms that reflect the divergence between the real wage faced by workers and employers.

In this framework the equilibrium unemployment rate is not uniquely determined by the wage setting equation alone-in contrast to the standard Phillips curve approach. However an expression analogous to the Phillips curve can be obtained by using equations (1) and (2) to eliminate the error correction term, $(w-p)_{t-1}-q_{t-1}$. This gives:

$\Delta(w-p)_{t}-\Delta q_{t}=\frac{\beta_{0} \alpha_{3}+\beta_{2} \alpha_{0}}{\alpha_{3}}+\frac{\left(\beta_{1}-1\right) \alpha_{3}-\beta_{2} \alpha_{2}}{\alpha_{3}} \Delta q_{t}+\frac{\beta_{3} \alpha_{3}-\beta_{2} \alpha_{1}}{\alpha_{3}} \Delta u_{t}-\frac{\beta_{2}\left(1-\alpha_{1}\right)+\beta_{3} \alpha_{3}}{\alpha_{3}} u_{t}-$ $\frac{\beta_{2}}{\alpha_{3}} z_{t}+x_{t}$

Thus the present model is consistent with a Phillips curve representation although both the real wage and unemployment are endogenous. In this representation faster productivity growth causes the productivity adjusted real wage to fall provided that $\beta_{1}<1$. As in the standard Phillips curve, provided that $\alpha_{1}<1$, the level of unemployment is negatively related to real wage. Also, the change in unemployment matters, but the sign is ambiguous, so that the 'speed limit' effect could be positive or negative.

In the matching model, productivity growth increases the value of recruitment to employers because the real wage does not increase by the full value of the productivity increase (Hall, 2005, p. 60). In our framework, as in the matching model, the level of productivity has no effect on unemployment in the long run because the real wage eventually catches up with productivity and unemployment depends only on the gap between the real wage and productivity. However, productivity growth will have long run effects on the equilibrium unemployment rate. This can be seen by obtaining the steady state unemployment rate, $u^{*}$, assuming a constant rate of productivity growth, $\Delta q=g^{*}$, and constant values for the wage/price pressure terms, $x^{*}$ and $z^{*}$.This can be derived by solving for the dynamics in equations (1) and (2) or, equivalently, by setting the left hand side of (3) to zero (and setting $\Delta u=0$ ), to give: 
$u^{*}=\frac{\alpha_{0}+\alpha_{3} \beta_{0} / \beta_{2}-z^{*}+\alpha_{3} x^{*} / \beta_{2}-\left[\alpha_{2}+\alpha_{3}\left(1-\beta_{1}\right) / \beta_{2}\right] g^{*}}{1-\alpha_{1}+\alpha_{3} \beta_{3} / \beta_{2}}$

This provides a useful benchmark for assessing the influences on the average level of unemployment across different eras of labour market history. According to (4), equilibrium unemployment will be a positive function of the shift terms in $x^{*}$ and a negative function of those in $z^{*}$. These effects will be greater the larger are $\alpha_{1}$ and $\beta_{2}$ and the smaller are $\alpha_{3}$ and $\beta_{3}$. Thus the equilibrium unemployment will be higher the less the real wage is responsive to unemployment and the slower it adjusts to the productivity gap, the more persistence there is in unemployment and the larger the response of unemployment to the productivity gap.. It is also worth noting that the effect of productivity growth will be more negative the higher are $\alpha_{1}$ and $\alpha_{2}$ and the lower are $\beta_{1}$ and $\beta_{3}$. Thus the bigger is the direct effect of productivity growth on unemployment and the smaller is its effect on the real wage, and the longer are the lags, the greater will be the effect of productivity growth on equilibrium unemployment.

\section{The Wage Setting Process}

The model set out above is designed to reflect Australia's wage setting institutions. For most of the twentieth century wage setting has been dominated by a centralised wage fixing mechanism. ${ }^{3}$ From 1907 until 1956 the key national wage decisions were made by the Commonwealth Arbitration and Conciliation Court, which was succeeded from 1956 by the Commonwealth Arbitration and Conciliation Commission, renamed the Australian Industrial Relations Commission in 1988. Centralised wage setting was significantly weakened only at the end of the century with the introduction of enterprise bargaining in 1996.

The federal tribunals were given the principal duty of preventing and settling industrial disputes. In so doing the panel of judges set a wage that they deemed to be fair and reasonable under the circumstances. The arbitration tribunal first established in 1904 had its roots in the federal convention of 1898 and was foreshadowed by tribunals or wage boards set up by individual colonies (later States) from the 1890s. Federal and State level wage setting operated side by side and it was not until the late 1920s that the Commonwealth Court accounted for more than half of all negotiated wage adjustments (Hancock, 1984, p. 48). The influence of national wage decisions increased, and as early as the 1920s the setting of a basic

\footnotetext{
${ }^{3}$ The large literature on centralized wage determination; some of the more important contributions are included in the volumes edited by Isaac and Ford (1967), Niland (1986), and Chapman et.al. (1984). More recent developments are examined by Wooden (2000). For a century long retrospective on wage fixing, see Isaac and Macintyre (eds.) (2004).
} 
national wage was seen as a focal point, or coordinating mechanism, for wage negotiations more generally and therefore as a means of averting disputes that might otherwise arise. ${ }^{4}$

The landmark judgement that shaped the system was that made by Justice Higgins in the 1907 Harvester case. In the Harvester judgement, Higgins set a basic wage that was justified as the minimum necessary to provide a civilised but frugal level of subsistence for the average unskilled workman. This established the principle that a basic wage would be set first and foremost by reference to the cost of living and from 1914 it was set with explicit reference to the change in the retail price index (later the consumer price index). Award wage rates for more skilled workers were linked to the basic wage; and from 1954 through explicit secondary margins, using the wage for fitters in the metal trades as a yardstick. From 1967 the basic wage and secondary margin was consolidated in the total wage (Isaac, 2008).

During the 1990s there was a shift away from centralised wage fixing and towards decentralised wage bargaining, beginning in 1992 with amendments to the Industrial Relations Act, followed in 1993 by the Industrial Relations Reform Act. The Workplace Relations Act of 1996 restricted the powers of the Australian Industrial Relations Commission, abolishing compulsory arbitration and introducing individual contracts into the Federal system. By 2000 more than 40 percent of Federal award employees were covered by individual contracts.

A number of key criteria have been used in wage fixing, the most important of which is the cost of living. From 1914 to 1953 the basic wage was linked more or less directly to the change in the retail price index, particularly from 1921 when it was adjusted on a quarterly basis. In the early years the wage was not adjusted during the life of an existing agreement and delays in adjustment to wartime inflation led to declines in the real wage. A Royal Commission of 1919/20 (the Piddington Commission) readjusted the basic wage in 1921 . From that time onwards the system preserved real wages, subject to other considerations. Although automatic cost of living adjustment was abandoned in 1954, it remained a key criterion in wage decisions. The automatic link with prices was revived in 1961-4 and again from 1975 to 1981 when it was known as indexation. After a brief interlude wage indexation was reintroduced in 1983 under the Accord, although it gradually diminished in importance.

Other considerations entered into the determination of average earnings, either through the centralised wage determination process or through slippage between legislated

\footnotetext{
${ }^{4}$ Federal wage setting gained in importance though a broad interpretation of the original Act and specifically because of the duty to consider disputes extending beyond the limits of any one State.
} 
wages and earnings that became known as over-award payments or 'wage drift'. The first is labour market conditions and specifically the unemployment rate. One of the more famous episodes was the 10 percent cut in the nominal basic wage in the face of high unemployment in $1931 .^{5}$ In the 1970 s and especially under the Accord in 1983-96 wage rates were explicitly set with an eye to labour market conditions, actual or incipient. The Accord is seen as a reaction to the increase in wage pressure since the mid 1970s and the corporatist approach to wage setting during this period was explicitly designed to keep unemployment in check (Chapman 1998, p. 628).

In the early years of centralised wage setting a criterion that quickly emerged was that of capacity to pay and from the 1920s the economy-wide productivity growth became a regular feature in wage arbitration. This was discussed by the Piddington Commission and it emerged again in the context of the 1931 wage cut. From 1953 to 1967 capacity to pay was a major criterion in national wage cases (Niland and Isaac 1975) and it remained an important consideration through to 1987 when productivity bargaining was formalised under the Accord.

Thus throughout the twentieth century wages were linked, more or less formally, to the cost of living and other adjustments were made relative to this benchmark. Both the 'target wage' and the 'feasible wage' were represented in wage setting decisions; the former by unemployment and labour market conditions more generally, and the latter by productivity growth as the key component of capacity to pay. However the central locus of bargaining has been the tension between the needs principle that was established with the Harvester judgement and the capacity to pay principle. The model set out above attempts to capture these central elements of the wage setting process.

\section{Labour Market Fundamentals}

Here we review the long term trends in some of the key variables that will later be used to explain wage adjustment and unemployment. The means of these variables are presented in Table 1 and the sources and methods of construction are given in the Appendix. We divide labour market history into three major eras, 1902-41, 1942-73 and 1974-2007.

As noted earlier the average unemployment rate in the middle period was less than a third of that before or after. Equally well known is the fact that productivity growth

\footnotetext{
${ }^{5}$ The Arbitration Court also allowed for a 10 percent decline in the cost of living so that the total nominal cut was 20 percent.
} 
accelerated after the Second World War, with some subsequent slowdown. When unemployment and productivity growth are strongly smoothed (Figure 2) an inverse relationship emerges and it is tempting to link faster productivity growth to lower unemployment. However, nominal wages and prices rose faster after 1941 than before and the net effect (Table 1, row 5) is that real wage growth increased between the first and second periods but slowed again after 1973. This can be compared with the growth rate of productivity (row 2), which shows that real wage growth consistently outstripped productivity growth up to 1973 and then grew more slowly than productivity in the subsequent era. As shown in the sixth row, the ratio of the real wage to labour productivity increases strongly across the three periods. However, the consumer price index relative to the GDP deflator (row 7) exhibits the opposite trends so that there is essentially no trend in long run unit labour costs. While workers' gross living standards increased relative to their productivity, much of that gain was offset by the rising direct tax share (row 8).

There follow three variables representing wage pressure. From about 5 percent at the turn of the century union density increased strongly in the next two decades and again during World War II. From a peak of 47 percent in the mid-1970s it fell to less than 20 percent by 2004. If unionism contributed to wage pressure then it would have been felt most strongly in the early postwar period when unemployment was at its lowest. Following Allard (2005) the expected net replacement rate (row 10) is the (net) benefit to wage ratio multiplied by indexes that represent the probability of receiving benefit — essentially a mix of eligibility for entering benefit and the duration for which it could be received (see Appendix). The overall index takes the value of zero before 1946 and it rises steeply during the 1970s with the increase in benefits and the widening of eligibility. If unemployment benefits served to increase reservation wages then this could have increased wage pressure between the second and third labour market eras. ${ }^{6}$

A number of other measures are often seen as affecting unemployment directly. Real interest rates are potentially important in models of labour market matching, where there is a cost to posting vacancies, (Pissarides, 2000, Pissarides and Vallanti, 2007). Faster productivity growth potentially increases the future returns to a job match while a higher interest rate reduces its present value. Another potential candidate is structural change; increasing turbulence may increase aggregate unemployment (Lilien, 1982). Our measure of

\footnotetext{
${ }^{6}$ Some observers stress the difference in wage pressure between the short-term unemployed, who are more likely to receive benefits, and the long-term unemployed, who may be less effective at job search. Unfortunately we have no such measure for the whole century.
} 
structural change is defined as $\mathrm{S}_{\mathrm{t}}=\Sigma_{\mathrm{i}} \mathrm{W}_{\mathrm{i}}\left|\mathrm{g}_{\mathrm{i}, \mathrm{t}}-\mathrm{g}_{\mathrm{t}}\right|$, where $\mathrm{w}_{\mathrm{i}}$ are the employment share weights, $\mathrm{g}_{\mathrm{i}, \mathrm{t}}$ are one year growth rates of employment in individual industrial sectors and $\mathrm{g}_{t}$ is employment growth in aggregate. This index ranges between zero (when employment in all sectors grows at the same rate as the aggregate and hence there is no structural change) and one. As illustrated (row 12), structural change was highest before 1941 and it could potentially have contributed to higher unemployment in the first four decades of the century.

Two types of economic shocks that are widely believed to influence unemployment are world trade and oil prices. Even though demand shocks should have no influence in the long run, the growth of demand is sometimes seen as influencing unemployment, either directly or through firms' expectations. For a century-long perspective, we proxy world demand by the growth rate of real income in Western Europe and North America (row 13). The fuel price (row 14) is the domestic price of fuels, especially petrol, relative to the GDP deflator. In the early postwar period world income grew faster and real fuel prices were lower than before or since and so it is possible that these variables contributed to lower unemployment in 1942-73.

\section{The Real Wage Equation}

Here we estimate the wage setting model, taking the dependent variable as the change in the real wage, using the cost of living deflator, which as noted above has been the benchmark for wage adjustment. As current productivity growth is potentially endogenous we use the value of productivity growth predicted from a first stage regression of productivity growth on its own lagged value and current and lagged values of world income growth as well as two period dummies and a time trend. The results appear in Table $2 .^{7}$ In the baseline model, equation (1), the coefficient on productivity growth is positive and significant and the effect of the unemployment rate is negative as predicted, though not significant. The error correction term is negative, although the coefficient is small, indicating fairly slow adjustment. The price wedge term is also negative but it is larger than would be expected if price wedge shocks are shared between workers and firms. Neither of the period dummies is significant although that for 1903-41 is stronger that for 1942-73. We also test the restriction of equal and opposite signs on the lagged real wage and lagged productivity by adding a

\footnotetext{
${ }^{7}$ Unit root tests on the key variables in the baseline model (Col. 1) indicates that these are all $\mathrm{I}(0)$. The ' $\mathrm{t}$ ', statistics for the Dickey Fuller test with one lag and drift are: $\Delta \log (\mathrm{W} / \mathrm{PC}),-7.78 ; \Delta \log (\mathrm{Q}),-11.24 ; \log (\mathrm{U}),-$ 2.46; $\log ((\mathrm{W} / \mathrm{PC})-\log (\mathrm{Q})),-2.78 ; \log (\mathrm{PC} / \mathrm{PG}),-2.11$.
} 
separate term for lagged productivity. This gave a ' $t$ ' statistic of 0.65 and hence long run homogeneity is not rejected.

In column (2) the 1942-73 dummy is dropped and dummies for the two World Wars 1914-18 and 1939-45 are added. The dummy for World War 1 is significantly negative, consistent with the lack of indexation for that period noted in the literature, and the coefficient on unemployment now becomes significant. Column (3) drops the World War 2 dummy and adds the lagged value of trade union density, which is positive but not significant. In column (4) a further two variables are added, the adjusted replacement ratio and the direct tax share. While these are both positive, as predicted, neither is significant. Thus it appears that the wage pressure variables representing outside options are fairly weak in the annual time series.

In columns (4) and (5) and (6) we impose the restriction (which is easily accepted) that the coefficients on the error correction term and the price wedge term are close to equal and opposite. This implies that in the long run shifts in the cost of living relative to the GDP deflator fall entirely on wage earners. Thus, although wage rates have historically been linked to the cost of living, this has been compensated by capacity-to-pay adjustments. In column (5) we also test for shifts in the wage setting process that have been highlighted in the literature for the period from 1974 onwards, by introducing three dummies. The dummies for the 'wage push' of 1974-82 and the period of enterprise bargaining 1997-2007 both give positive coefficients that are significant at the 10 percent level while that for the period of the Accord 1983-96 is close to zero.

In column (6) the latter is dropped and all the remaining coefficients are significant at the 5 percent level. When the restrictions implied by (6) are tested against the most general model (specification (5) plus World War 2 and three post-1973 period dummies) they are not rejected $\left(\mathrm{F}_{5,92}=1.08\right)$. Other period dummies have little effect when added individually to equation (6). Dummies for the interwar period following the readjustment of the basic wage (1922-39) or for the Great Depression (1930-9), gave insignificant coefficients (' $t$ ' $=0.05$ and 0.91 respectively). Thus, the picture that emerges from these results is that wage pressures were particularly strong in the period up to 1941 and then again in 1974-82 and 1997-2007. This seems to be largely consistent with industrial relations history. 1974 saw a return to the more adversarial pre-War climate, which was replaced by a more consensual or corporatist approach under the Accord (see Chapman 1998). Enterprise bargaining evidently undid the effects of the Accord but without a return to industrial strife. 
Several additional hypotheses were tested on equation (6). First, it might be argued that the effect of unemployment has become weaker over time, perhaps as a result of structural change or alternative income, especially from the 1970s (Gregory, 1986). However interactions of unemployment with two period dummies, 1942-73 and 1974-2007 gave insignificant coefficients (' $\mathrm{t}$ ' $=1.06$ and 0.20 respectively). Another suggestion is that the wage push of the 1970s might be accounted for by the oil shocks, but the real price of oil did not prove to be significant (' $\mathrm{t}$ ' $=0.29$ ). Neither is there strong evidence that productivity growth had different effects across periods; interactions between productivity growth and period dummies for 1942-73 and 1974-2007 also proved insignificant ('t' $=1.01$ and 0.13 respectively). Finally, as before, long run homogeneity between the real wage and productivity is not rejected, ' $\mathrm{t}$ ' $=0.91$.

\section{The Unemployment Equation}

Estimates of the unemployment equation are presented in Table 3. As column (1) shows, there is strong persistence in unemployment, as reflected in coefficient on the lagged dependent variable.. Productivity growth gives a strong negative coefficient and the dummy for 1942-73 indicates a large and significant downward shift in unemployment for given fundamentals during the early postwar years. In the second column the dummy for 1903-41 is replaced by dummies for the two world wars, both of which are negative, which is consistent with an overall negative shock to labour supply, although only that for the First World War is significant at the 5 percent level. The lagged ratio of the real wage to productivity now gives a positive and significant coefficient, consistent with the labour demand interpretation of the unemployment equation. Although the price wedge term is not significant, the coefficients on the price wedge and the ratio of the real wage to productivity are now similar in magnitude, suggesting that it is the product wage that determines unemployment in the long run.

The third column adds the real interest rate and the structural change index. As noted earlier, a higher interest rate reduces the present value of a job match which increases equilibrium unemployment. This gives a significant negative coefficient, as predicted. Although structural change is sometimes thought to reduce matching efficiency leading to higher unemployment, the coefficient is insignificant. Column 4 includes two additional variables, which are often thought to be important determinants of unemployment. The effect of real fuel prices, by increasing costs, is interpreted as causing a negative shift in labour demand in the 1970s. But the coefficient is negative, contrary to expectation, and not significant. Second, 'world' income growth (specifically Europe and North America) can be 
interpreted as a real demand shock. This gives a negative but insignificant coefficient, a result that is not altered in column (5).

Column (5) drops the real fuel price and includes an interaction between lagged unemployment and the period dummy for 1942-73, which is significantly negative. As noted earlier, equilibrium unemployment will be higher the greater the persistence in unemployment. Persistence seems to have been lower in the early post-war period and, in the presence of the negative interaction term, the main effect of the period dummy becomes insignificant. In the last column we present a more parsimonious specification, dropping world growth and the period dummies for World War 1 and 1942-73, and imposing the restriction of equality between the price wedge and the ratio of the real wage to productivity. This is a valid restriction of a more general model that includes all the variables in Table 3 $\left(\mathrm{F}_{8,91}=1.40\right)$. Several other tests were performed on this model. Adding a second lag of the unemployment rate produced an insignificant coefficient ( $(' t=0.79)$, suggesting that only first order persistence matters. Interacting productivity growth with period dummies for 1942-73 and 1974-2007 give insignificant coefficients (' $\mathrm{t}$ ' $=0.82$ and 0.24 respectively) as did similar interactions with the real interest rate (' $t$ ' $=1.15$ and 0.24 respectively).

\section{Calculating the Equilibrium Unemployment Rate}

One way of assessing the contribution of different variables to the average unemployment rate across broad periods is to calculate equilibrium unemployment for each period using the empirical counterpart to equation (4) above. This is calculated by setting all the variables to their period means and using the estimated wage equation in the last column of Table 2 and the estimated unemployment equation in the last column of Table 3 . The first row of Table 4 is the observed average unemployment rate for each of the three periods while the second row is the calculated value of the equilibrium unemployment rate. Not surprisingly, this is close to the average unemployment rate for each period although it is a little below the mean unemployment rate 1903-41 and 1974-2007.

In the subsequent rows of Table 2 the equilibrium unemployment rate is calculated holding one or more of the variables constant at the average level prevailing in the period 1903-41. Thus the value is always the same in the first column, and the second and third columns isolate the contribution of each of the variables to differences in the equilibrium unemployment rate by comparison with that in the second row. The third row shows that, had the union density remained at the level of 1903-41, the equilibrium unemployment rate would 
have been a shade lower in the early postwar period and about one percentage point lower after 1973. Row (4) applies the 1903-41 dummy in the wage equation to the later periods but drops the dummies for 1974-82 and 1997-2007. Thus there is a constant 'wage push' across all periods. This raises unemployment in the early postwar period, and it substantially increases unemployment after 1973 despite eliminating the wage push effects of 1974-82 and 1997-2007. The fifth row shows the effects of holding both union density and wage pressure constant. This produces a pattern very similar to the equilibrium unemployment rate in row (2), suggesting that these effects were largely offsetting.

The sixth row shows that lower real interest rates after 1941 contributed modestly to lower unemployment in the subsequent periods. Similarly row (7) shows that faster productivity growth reduced equilibrium unemployment after 1941. This effect is shown in equation (4) above and is consistent with empirical findings for other countries. ${ }^{8}$ But a more substantial effect is the change in the dynamics of the unemployment equation. As row (8) shows, in the absence of this shift, equilibrium unemployment in 1942-73 would have been higher by about three percentage points. Finally, row (9) shows the combined effects of the real interest rate, productivity growth and the shift in unemployment dynamics. Each of these tended to lower equilibrium unemployment in the early postwar years, and in the absence of these shifts the equilibrium unemployment rate would have averaged between six and seven percent in all three periods.

Our results for the period since the 1960s are of particular interest because of the shifts in the wage push variables. For the periods 1964-73, 1974-82, 1983-96 and 1997-2007, the mean unemployment percentages were, respectively, 1.67, 5.39, 8.44 and 6.15 . The calculated equilibrium unemployment rates are, respectively, 1.85, 6.57, 5.79 and 5.79. In accordance with other studies based on the Phillips curve, there is a rise in equilibrium unemployment in the mid-1970s from about 2 percent to 5-6 percent (Borland and Kennedy, 1998, p. 71; McDonald 2002, p. 465). It also accords with some studies that estimate timevarying NAIRUs. Thus Gruen et al. (1999) estimate the NAIRU at about 6 percent in 197482, falling to around 5 percent from 1983; Kennedy et al. (2008) find a similar pattern followed by a decline from 6 percent in 2000 to 4.7 percent in 2007. Crosby and Olekalns (1998) find a progressive increase in the NAIRU, rising from 2.3 percent in 1959-73 to 5.0

\footnotetext{
${ }^{8}$ Ball and Mankiw (2002) find that productivity growth influences the NAIRU in the US; they use a standard Phillips curve framework where 'wage aspirations' adapt slowly to productivity growth. Slacalek (2004) provides multi-country evidence in support of an inverse relationship between productivity growth and the NAIRU.
} 
percent on 1974-84 and 9.2 percent in 1984-97. Similarly Lim et al. (2009) find that the NAIRU increased during in the 1970s and 1980s, reaching a peak of 8.9 percent in 1993 and then declining to about 5 percent in 2008 .

In our model the upward shift in equilibrium unemployment that occurred in the 1970s is accounted for mainly by a shift in the dynamics between unemployment and its determinants, and only to a lesser extent by an increase in wage pressure. ${ }^{9}$ Nevertheless it is consistent with the results of recent studies that use a Philips curve approach. In the Phillips curve representation of our model (equation 3) an increase in the size of the persistence parameter, $\alpha_{1}$ makes the Phillips curve become flatter and makes the speed limit effect become less negative. Thus in their recent study, Lim et al. (2009) find a substantial downward drift in the slope of the Phillips curve from the mid-1970s. And in their range-ofunemployment estimates Lye et al. (2001) find that the unemployment effect and the speed limit effect both became less negative after the mid-1970s. Although these results are consistent with ours, the interpretation is different. We suggest that it is due to a shift in unemployment dynamics rather than a shift in the wage setting process.

The change in unemployment persistence (or hysteresis) has been the focus of a number of studies, particularly those concerned with the rise in European unemployment, but its causes are still not well understood (Røed, 1997; Ball and Mankiw, 2002). One possible explanation of rising unemployment persistence is an increase in the power of insiders within firms. But if this was associated with strong trade unionism then persistence should have been most marked before the mid-1970s rather than subsequently. Other explanations include loss of employability due to deskilling, perhaps associated with structural change; or alternatively, duration dependence in combination with more generous unemployment benefits. But one reason to be sceptical about such arguments is that unemployment persistence was relatively high not only from the mid-1970s but also in the period before 1942.

\section{Unemployment and Wage Policy}

There are long-running debates about wage policy in different periods and here we focus on four important eras in the history of wage setting. We evaluate their effects of policy

\footnotetext{
${ }^{9}$ Most studies have difficulty in explaining this shift in terms of variables that enter the Phillips curve. Using a model more closely related to ours Pissarides (1991, p. 49) attributes most of the increased wage pressure to the tax wedge, which according to his estimates added more than 4 percentage points to the NAIRU between 19703 and 1976-9.
} 
on unemployment by simulating the dynamic two equation system under alternative counterfactual assumptions, using equation (6) in Table 2 and equation (6) in Table $3 .{ }^{10}$ It is worth noting in passing that some of the events that we study are once-and-for-all wage adjustments that, in the present framework, have effects that feed back into unemployment but which gradually dissipate as the labour market adjusts. Such effects are more difficult to analyse in the standard single equation Phillips curve where the typical approach has been to introduce dummies for a series of years. This essentially tests for effects on wage growth over the policy period rather than for the effect of a single step in the wage level on unemployment.

Perhaps the most famous wage adjustment was the Harvester judgement, which, in 1907, set a basic wage for unskilled workers of 42 shillings, an increase of about 27 percent. Here we make two assumptions about its impact. The first is that we assume that the effect on average real earnings across all skill levels was somewhat smaller-15 percent. ${ }^{11}$ The second is that it did not become effective until 1912, when the basic wage was adjusted upwards in light of the newly established cost of living index. ${ }^{12}$ The counterfactual undoes this adjustment by introducing a negative shock of 15 percent in 1912. The dashed line in Figure 3 shows the effect of this wage shock using a dynamic simulation of the two equation model. In the absence of the Harvester wage increase the unemployment rate would have been lower by a maximum of 1.3 percentage points in 1915 . Thereafter the effect fades as the labour market adjusts, so that the effect disappears after about eight years.

As noted earlier, real wages were eroded by inflation during the First World War, and this effect is captured by the dummy in the wage equation for the war years 1914-1918. The effect of removing the war dummy is that unemployment would have been higher, on average, by 2.0 percentage points from 1916 to 1922. Thus, while the implementation of the Harvester award increased unemployment, this effect was more than offset by the erosion of the real wage during the War, and this effect persisted until well after the War.

\footnotetext{
${ }^{10}$ We simulate the recursive system using the actual values of all the exogenous variables, also including the equation errors in order to identify the counterfactual effects alone.

${ }^{11}$ This assumes that the effects were marginal further up the wage distribution, which would be consistent with the narrowing of skill differentials before the First World War noted by Macarthy (1972).

${ }^{12}$ According to Isaac "The seven shillings a day was not applied generally and percolated slowly though the system," and "it was not until 1912, coinciding with the publication by the Commonwealth Statistician of the first cost of living index, that Higgins adjusted the basic wage on claims that the cost of living had risen since 1907, , (2008, p. 288). Our wage equation also supports this interpretation, with a positive residual of 0.11 in 1912.
} 
As noted earlier, the real value of the basic wage was reassessed by the Piddington Commission; subsequently a once-and-for-all adjustment of three shillings a week was made by Justice Powers. While this would have added only 4 percent to the average wage, with prices falling, the wage might otherwise have been adjusted downwards in the absence of the award. ${ }^{13}$ In this light it has sometimes been argued that the readjustment of the basic wage froze the real wage at too high a level, adding to unemployment during the 1920s, and making adjustment to the demand shocks of the 1930s all the more difficult (Pope 1982, Valentine, 1988). Here we assume a counterfactual where the real wage is adjusted downwards by 15 percent in $1921 .{ }^{14}$ The dashed line in Figure 4 shows that unemployment would have been lower on average by about 1.2 percentage points between 1922 and 1925 . However, this effect had largely dissipated by the eve of the Great Depression.

Figure 4 also shows the effect of reversing the 10 percent real wage cut imposed by the Arbitration court in 1931. Some observers argue that the ex-post effect on the real wage was less than this because State-level tribunals did not follow the Commonwealth and/or because employers adjusted over-award payments. ${ }^{15}$ Here we simply introduce a positive 10 percent shock in 1931. Thus, supposing that the real wage cut was effective, the simulation in Figure 4 suggests that between 1932 and 1935 unemployment would have been higher by 2.7 percentage points than otherwise. ${ }^{16}$ It is notable that this effect is larger in absolute terms than the effect of raising the real wage a decade earlier. Given the structure of the model this is not surprising, but it runs counter to the view that wage cuts (if successfully implemented) are less effective in recessions.

One of the biggest wage shocks in the postwar period was the so-called wage explosion of 1973-4, which represented a breakdown in the wage setting process. This took place at the time of rapid increase in inflation associated with the first oil shock. But the wage

\footnotetext{
${ }^{13}$ It should be noted that the Tariff Board was set up in 1921, and this was seen as a way of sustaining higher real wages. Hancock (2004) discusses the debate that followed.

14 This figure is consistent with the estimate of Forster (1985), p. 385, and with the estimated residual in the wage equation for $1921(0.18)$.

${ }^{15}$ Gregory et al. (1988, p. 223-4) find that the reduction in the Commonwealth basic wage was not reflected at all in the all-industry or the factory wage series. Sheldon (2007) shows that, with the exception of Victoria and Tasmania, State tribunals did not follow the Commonwealth Court. Evidence for the compensating adjustment of margins for Bank employees is provided by Seltzer (2003). Hancock (2004, p. 419) also notes that "the components of minimum rates that were not adjusted to price movements rose in real value as prices fell and vice versa as prices recovered," implying that real wages might have risen in the absence of the cut.

${ }^{16}$ This is less than some estimates. For example, Valentine (1988, p. 168) finds that a sustained 10 percent wage cut from 1929-30 would have reduced the unemployment rate by an average of 4 percentage points in the four succeeding years.
} 
push more than compensated for the increase in the cost of living and it was locked in by the reintroduction of indexation from 1975. This is consistent with the significant dummy for 1974-82 in our wage equation, which suggests that the effect was not just a transitory shock. In the counterfactual simulation we undo this effect by eliminating the wage push dummy. As the dashed line in Figure 5 shows, the wage push effect gradually increased so that by 1982 unemployment would have been 1.8 percentage points lower in its absence. This is also the period when the shift occurs in the unemployment equation. As the dotted line shows, the 1974 wage push is dwarfed by the effects of the shift in the dynamics between unemployment and its determinants. In the absence of this shift unemployment would have been close to the pre-1974 average.

Finally, we examine the effect of deregulation of the labour market from 1996. We found that wage moderation under the Accord reversed the wage push effects of the late 1970s. But the dummy in the wage equation for 1997-2007 suggests that wage pressure increased again when corporatist wage setting was abandoned with the introduction of enterprise bargaining. And the permanence of this effect is consistent with a change in the structure of wage bargaining rather than being a once-and-for-all shock to the wage level, which would dissipate in a few years. The dashed line in Figure 6 shows the effect of removing the dummy in the wage equation for 1997-2007. This reduces unemployment by 1.7 percentage points by 2007 and by an average of 1.5 percent over the whole period.

Thus, ironically, deregulation unleashed wage pressure that had previously been suppressed under the Accord. But as noted earlier, trade unionism also declined steeply over this period. The dotted line in Figure shows the effect of keeping trade union density at its 1987 level in subsequent years. The fall in unionism from 1987 reduced the unemployment rate by an average of 2.3 percentage points over the subsequent years, rising to 2.7 percentage points by 2007. The decline in unionism after 1996 largely offsets the effect of the enterprise bargaining dummy and consequently the net effects of these two forces are modest.

\section{Conclusion}

We have attempted to model wage setting and unemployment over more than a century since Federation. A model that captures the key features of centralised wage setting works well over the century as a whole and it provides sensible equilibrium predictions in levels for both the real wage and the unemployment rate. The results suggest that both a wage setting equation and an equation for unemployment are necessary in order to assess equilibrium 
unemployment, in contrast to the single equation approach used in studies based on the Phillips curve.

While demand and wage pressure variables generally work in the expected direction, some of them are not very significant and they cannot account for the dramatic shifts to persistently low average unemployment rates from the early 1940s and then the return to an era of higher unemployment from the mid-1970s. The golden age of low unemployment 1942-73 appears to be the result of a change in the dynamics of the unemployment equation. This stands in contrast to the conventional Phillips curve approach that stresses shifts in the wage for given unemployment rather than in unemployment for a given wage. When combined with faster productivity growth and low real interest rates, this accounts for lower unemployment in the golden age 1942-73.

In the first half of the century policies that imposed once-and-for all wage adjustments had discernible effects that dissipated in the ensuing years as the labour market adjusted. But over the whole period up to 1942 wage pressure was stronger than during the following three decades and this seems to have been a permanent effect. Strong wage pressure returned in the mid-1970s but it was successfully suppressed by corporatist wage setting under the Accord. One of the key findings is that this wage pressure returned with the transition from corporatist wage setting to enterprise bargaining. However that effect seems to have been offset by the weakening bargaining strength of trade unions. Thus one important question for future research is to explore further these two effects using more disaggregated data for the period since the early 1980s. 


\section{Data Appendix}

Consumer Price Index Sources: a) 1900 to 1949: from Bambrick (1973) Table 1; b) 1949/50 to 1996/97: RBA Historical Statistics (annual data - financial year averages) Table 5.7a, weblink at: (http://www.rba.gov.au/Statistics/OP8ExcelFiles/5-7a\&b.xls); c) 1996/97 to 2007; RBA Historical Statistics, Table G02, weblink at (http://www.rba.gov.au/Statistics/Bulletin/G02hist.xls).

Nominal Wage Source: a) 1901 - 1911: weighted average of manufacturing weekly wages for Victoria and NSW from Macarthy (1970, p.61, 66), output weights from Butlin (1962), Table 87, p. 169; b) 1912 to 1939 and 1944 to 1968 from Vamplew (1987) Table: LAB 195 - 208, p. 161 (weighted average of male and female using weights from Table: LAB 227 - 228, p. 164); d) 1940 - 43: weighted average of male and female wages based on Butlin (1977), Table IV.4, p. 88; d) 1969 to 2007: RBA Historical Statistics Table G06, average weekly earnings all employees, adjusted to full time earnings, weblink at:(http://www.rba.gov.au/Statistics/Bulletin/G06hist.xls).

Unemployment Rate $\quad$ Sources: a) 1901 to 1964: Vamplew (1987), Table: LAB 86-97, column 97, p. 152; b) 1965 to 1996: RBA historical statistics, Table 4.15, weblink at:

(http://www.rba.gov.au/Statistics/OP8ExcelFiles/4-15.xls); c) 1997 to 2007:RBA Bulletin Statistics, Table G07, weblink: (http://www.rba.gov.au/Statistics/Bulletin/G07hist.xls).

Civilian Employment Sources: a) 1901 to 1964: financial year averages from Butlin (1977), Table IV.5, p. 90; b) 1965 to 1997: RBA Historical Statistics, Table 4.3: weblink at: (http://www.rba.gov.au/Statistics/OP8ExcelFiles/4-3.xls); c) 1998 to 2007 : RBA Bulletin Statistics (monthly data) Table G07, column 'Employed Persons, Total'. To maintain consistency the data for the month of August is used. The series was adjusted to full time equivalent by weighting part time employees as one half and using the share part time for 1978 to 2007 from RBA Table G07, column 'Employed Persons, Part Time and Full Time'; the share of part time was extrapolated back to zero in 1947.

Real GDP at Constant Prices $\quad$ Source: a) 1901 to 1949: financial years from Butlin, (1977), Table IV.2; b) 1950 to 1996: GDP expenditure from RBA Historical Statistics, Table 5.2a, weblink (http://www.rba.gov.au/Statistics/OP8ExcelFiles/5-2a\&b.xls); c)1997 to 2007: GDP expenditure (quarterly, converted to financial years), RBA Historical Statistics, Table: G11, weblink: (http://www.rba.gov.au/Statistics/Bulletin/G11hist.xls).

Implicit GDP Deflator Source: a) 1901 to 1949: financial years from Butlin (1977), Table IV.2; b) 1950 to 1996 is from RBA Historical Statistics, Table 5.6a, weblink (http://www.rba.gov.au/Statistics/OP8ExcelFiles/56a\&b.xls); c)1997 to 2007: RBA Historical Statistics (quarterly data) Table: G04 OTHER PRICE

INDICATORS, column Gross Domestic Product chain price indices (2006 = 100 as the base year), converted into financial year averages (ie. average of Sep t-1, Dec t-1, Mar t, Jun t), weblink:

(http://www.rba.gov.au/Statistics/Bulletin/G04hist.xls). We make adjustments so that the entire series is with $1990=100$ as the base year.

Nominal Interest Rate Sources: a) 1901 to 1983: annual percentage interest rate on government bonds from Vamplew (1987), Table: PF1-5, column 3, p. 240; b) 1984 to 1996: Yield on 2 year Treasury bonds : RBA Historical Statistics Table 3.23, weblink at: (http://www.rba.gov.au/Statistics/OP8ExcelFiles/3-23.xls); c) 1997 to 2007: Yield on 5 year government bonds: RBA Historical Statistics F02, weblink at: (http://www.rba.gov.au/Statistics/Bulletin/F02hist.xls).

Price of Fuel Sources: a) 1900 to 1913: Bambrick (1970) proxied by 'price of Raw Materials and semimanufactures'; b) 1914 to 1918: Vamplew (1987) pp. 215-216 proxied by the weighted average of wholesale price of chemicals in Victoria and New South Wales using manufacturing output from Butlin (1962) as weights; c) 1919 to 1927: Bambrick (1970) proxied by 'price of Chemicals'; d) 1928 to 1950: Bambrick (1970) proxied by 'price of Oil'; e) 1951 to 1966: Bambrick (1970) proxied by 'price of Fuel and Lubricants'; f) 1967 to 1995 : RBA historical Statistics Tables $1.13 \mathrm{a} \& \mathrm{~b}$, series 'Fuel and Lubricants' and 'Minerals fuels and lubricants'; g) 
1996 to 2007: RBA statistical Bulletin, table G05, proxied by non-rural component of commodity price index. All indices are converted to base $1990=100$ wherever necessary.

Structural Change Index Defined as $\mathrm{S}_{\mathrm{t}}=\Sigma_{\mathrm{i}} \mathrm{wi}\left|\mathrm{g}_{\mathrm{i}, \mathrm{t}}-\mathrm{g}_{\mathrm{t}}\right|$, where $\mathrm{w}_{\mathrm{i}}$ are the employment share weights, $\mathrm{g}_{\mathrm{i}}$ and $\mathrm{g}$ are one year growth rates of employment in individual industrial sectors and the economy respectively. This index ranges between zero (when employment in all sectors grows at the same rate as the aggregate and hence there is no structural change) and one. Sources: a) 1911-1980: Calculated using Withers et al. (1985); b) 1981 to 1997: Index constructed using RBA Historical Statistics Table 4-10; c) 1998 to 2007: Index constructed using ABS data (cat no. 6291.0.55.033) - Table 04; for the early years to 1910 the index is calculated using output data from Vamplew (1987), p. 133

Trade Union Density $\quad$ Defined as trade union membership as a proportion of employment. Sources: a) 1901 and 1906-1984: Withers et al. (1985), pp. 172-73; b) 1990 and 1992-2006: ABS (cat no. 6310.0) - Table: Trade Union Membership Time Series.

Replacement Rate $\quad$ Net replacement ratio adjusted for coverage and duration. Sources: a) 1950-2007: data kindly supplied by Gayle Allard, as updated from Allard (2005), p. 14; 1901-50: assumed to be zero until 1947 then the same value as the 1950s.

Direct Tax Share $\quad$ Share of Income Tax to Nominal GDP. Sources: a) 1901 -1948: Vamplew (1987), Table GF 357-367, p. 282; b) 1949- 1995: RBA Historical Statistics, Table 2-17; c) 1996- 2007: RBA Statistical Bulletin, Table E01.

Data References

Allard, G. (2005), "Measuring the Changing Generosity of Unemployment Benefits: Beyond Existing Indicators," IE Working Paper No. WP05-18, Madrid: Instituto de Empressa.

Bambrick, S. (1970) Australian Price Indexes, ANU PhD thesis.

Bambrick, S. (1973), "Australian Price Levels, 1890-1970," Australian Economic History Review, 13, pp. 57-7.

Butlin, N. G. (1962), Australian Domestic Product, Investment and Foreign Borrowing 1861 - 1938/39

Butlin, M. (1977). "A Preliminary Annual Database 1900/01 to 1973/74," RBA Research Discussion Paper No. 7701.

Macarthy, P. G. (1970), "Wages in Australia, 1891-1914,"

Vamplew, W. (ed.) (1987), Australians, Historical Statistics, Broadway, NSWs: Fairfax, Syme \& Weldon Associates. 


\section{References}

Allard, G. (2005), "Measuring the Changing Generosity of Unemployment Benefits: Beyond Existing Indicators,” IE Working Paper No. WP05-18, Madrid: Instituto de Empressa. Ball, L, and Mankiw, N. G. (2002), “The NAIRU in Theory and Practice,” Journal of Economic Perspectives, 16, pp. 115-136.

Bell, B., Nickell, S. and Quintini, G. (2002), "Wage Equations, Wage Curves and All That," Labour Economics, 9, pp. 341-360.

Blanchard, O. (2007), “Review of Richard Layard, Stephen Nickell and Richard Jackman's Unemployment, Macroeconomic Performance and the Labour Market," Journal of Economic Literature, 45, pp. 410-418.

Blanchard, O. and Katz, L. F. (1997), "What We Know and Do Not Know About the Natural Rate of Unemployment," Journal of Economic Perspectives, 11, pp. 51-72.

Blanchard, O. and Gali, J. (2008), “Labor Markets and Monetary Policy: A New Keynesian Model with Unemployment,” NBER Working Paper13897, Cambridge MA: NBER.

Borland, J and Kennedy, S. (1998), Dimensions, Structure and History of Australian Unemployment," in G. Debelle and J. Borland (eds.), Unemployment and the Australian Labour Market, Sydney: Reserve Bank of Australia.

Borland, J. and McDonald, I. M. (2000),'Labour Market Models and Unemployment in Australia,” Melbourne Institute Working Paper WP 15/00.

Chapman, B. J. (1998), "The Accord: Background Changes and Aggregate Outcomes," Journal of Industrial Relations, 40, pp. 624-642.

Chapman, B. J., Isaac, J. E. and Niland, J. R. (eds.) (1984), Australian Economics: Readings, Melbourne: Macmillan. Crosby, M. And Olekalns, N. (1998), "Inflation, Unemployment and the NAIRU in Australia," Australian Economic Review, 31, pp. 117-129.

Debelle, G. and Vickery, J. (1998a), "Is the Phillips Curve Really a Curve? Some Evidence and Implications for Australia," Economic Record, 74, pp. 384-398.

Debelle G. And Vickery, J. (1998b), “The Macroeconomics of Australian Unemployment," in G. Debelle and J. Borland (eds), Unemployment and the Australian Labour Market, Sydney: Reserve Bank of Australia.

Dimsdale, N. H. and Horsewood N. J. (2002), “The Causes of Unemployment in Interwar Australia," Economic Record, 78, pp. 388-405.

Forster, C. (1985), “Unemployment and Minimum Wages in Australia, 1900-30," Journal of Economic History, 45, pp. 383-388. 
Gregory, R. G. (1986), "Wage Policy and Unemployment in Australia,” Economica, 53 Supplement, S53 - S74.

Gregory, R. G., Ho, V. and McDermott, L. (1988), "Sharing the Burden: The Australian Labour Market in the 1930s," in R. G. Gregory and N. G. Butlin (eds.), Recovery from the Depression: Australia and the World Economic in the 1930s, New York: Cambridge University Press.

Gruen, D., Pagan, A. and Thompson, C. (1999), “The Phillips Curve in Australia," Journal of Monetary Economics, 44, pp. 223-258.

Groenewold, N. and Hagger, A. J. (1998), “The Natural Unemployment Rate in Australia since the Seventies," Economic Record, 74, pp. 24-35.

Hall, R. E. (2005), “Employment Fluctuations with Equilibrium Wage Stickiness,” American Economic Review, 95, pp. 50-65.

Hancock, K. J. (1984), “The First Half Century of Wage Policy,” in Chapman, B. J., Isaac, J. E. and Niland, J. R. (eds.), Australian Economics: Readings, Melbourne: Macmillan. Hancock, K. J. (2004), "Economists and Australian Wage Policy before World War II," Australian Journal of Labour Economics, 7, pp 413-438.

Hatton, T. J. and Boyer, G. R. (2005), "Unemployment and the UK Labour Market Before, During and After the Golden Age," European Review of Economic History, 9, pp. $35-60$.

Hatton, T. J. (2007), “Can Productivity Growth Explain the NAIRU?” Long Run Evidence from Britain, 1870-1999," Economica, 74, pp. 475-491.

Isaac, J. E. and Ford, J. W. (eds.) (1967), Australian Labour Economics: Readings, Melbourne: Sun Books.

Isaac, J. E. and Macintyre, S. (eds.) (2004), The New Province for Law and Order: 100 Years of Australian Industrial Conciliation and Arbitration, Melbourne: Cambridge University Press.

Isaac, J. (2008), “The Economic Consequences of Harvester,” Australian Economic History Review, 48, pp. 280-300.

Kenwood, A. G. (1995), Australian Economic Institutions since Federation, Melbourne: Oxford University Press.

Kennedy, S. and Borland, J. (2000), “A Wage Curve for Australia?” Oxford Economic Papers, 52, pp. 774-803.

Kennedy, S., Luu, N. and Goldbloom, A. (2008), "Examining Full Employment in Australia Using the Phillips and Beveridge Curves, Australian Economic Review, 41, pp. 286- 
297.

Layard, R., Nickell, S. and Jackman, R. (2005), Unemployment: Macroeconomic Performance and the Labour Market ( $2^{\text {nd }}$ edn.), Oxford: Oxford University Press.

Lilien, D. M. (1982), “Sectoral Shifts and Cyclical Unemployment," Journal of Political Economy, 90, pp. 777-793.

Lim, G. C., Dixon, R, and Tsiaplias, S. (2009), "The Phillips Curve and Equilibrium Unemployment,” Economic Record, 85, pp.371-382.

Lye, J. M., McDonald, I. M. and Sibley H. (2001), “An Estimate of the Range of Equilibrium Rates of Unemployment in Australia," Economic Record, 77, pp. 35-50.

Lye, J. N. and McDonald, I. M. (2004), “The Effectiveness of Incomes Policies in Australia: Enterprise Bargaining and Inflation Targeting," Australian Economic Papers, 43, pp. 21-38.

Lye, J. N. and McDonald, I. M. (2006), “An Evaluation of Unemployment Policy in Australia," Australian Economic Review, 39, pp. 239-256.

Macarthy, P. G. (1972), “Wages for Unskilled Work and Margins for Skill,” Australian Economic History Review, 12, pp. 142-160.

Manning, A. (1993), "Wage Bargaining and the Phillips Curve: The Identification and Specification of Aggregate Wage Equations," Economic Journal, 103, pp. 98118.

McDonald, I. M. (2002), Equilibrium Unemployment: Theory and Measurement in Australia using the Phillips Curve," Economic Record, 78, pp. 451-470.

Niland, J. R. and Isaac, J. E. (1975), Australian Labour Economics: Readings, Melbourne: Sun Books.

Niland, J. (ed.) (1986), Wage Fixation in Australia, Sydney: George Allen and Unwin.

Pissarides, C. A. (1991), "Real Wages and Unemployment in Australia," Economica, 58, pp. 35-65.

Pissarides, C. A. (2000), Equilibrium Unemployment Theory, Cambridge MA: MIT Press.

Pissarides, C. A. and Vallanti, G. (2007), "The Impact of TFP Growth on Steady-State Unemployment," International Economic Review, 48, pp. 607-640.

Pope, D. H. (1982), “Wage Regulation and Unemployment in Australia, 1900-30," Australian Economic History Review, 22, pp. 103-126.

Røed, K. (1997), “Hysteresis in Unemployment,” Journal of Economic Surveys, 11, pp. 389418. 
Seltzer, A. J. (2003), “Can Incomes Policies Reduce Real Wages? Micro-evidence from the 1931 Australian Award Wage Cut," Research in Economic History, 21, pp. 105-133. Sheldon, P. (2007), "State-level Basic Wages in Australia during the Depression, 1929-35: Institutions and Politics over Markets," Australian Economic History Review, 47, pp. 249-277.

Shimer, R. (2005), "The Cyclical Behaviour of Equilibrium Unemployment and Vacancies," American Economic Review, 95, pp. 25-49.

Slacalek, J. (2004), "Productivity and the Natural Rate of Unemployment," DIW Discussion Paper 562, Berlin: DIW. Valentine, T. J. (1988), "The Battle of the Plans: A Macroeconometric Model of the Interwar Economy," in R. G. Gregory and N. G. Butlin (eds.), Recovery from the Depression: Australia and the World Economic in the 1930s, New York: Cambridge University Press.

Watts, M. And Mitchell, W. (1990), “Australian Wage Inflation: Real Wage Resistance, Hysteresis and Incomes Policy: 1968(3) to 1988(3)," Manchester School, 58, pp. 142164.

Wooden, M. (2000), The Transformation of Australian Industrial Relations Reform, Sydney: Federation Press.

Wooden, M. (2001), “Industrial Relations Reform in Australia: Causes, Consequences and Prospects," Australian Economic Review, 34, pp. 243-262. 
Table 1

Economic Fundamentals in three Eras

\begin{tabular}{|l|c|c|c|}
\hline \multicolumn{1}{|c|}{ Variable } & $\mathbf{1 9 0 2 - 1 9 4 1}$ & $\mathbf{1 9 4 2 - 1 9 7 3}$ & $\mathbf{1 9 7 4 - 2 0 0 7}$ \\
\hline 1) Unemployment rate & 7.11 & 1.86 & 6.86 \\
\hline 2) Growth rate of labour productivity & 0.84 & 1.79 & 1.70 \\
\hline 3) Growth rate of nominal weekly earnings & 3.03 & 7.37 & 7.13 \\
\hline 4) Growth rate of consumer price index & 1.63 & 4.61 & 6.08 \\
\hline 5) Growth rate of real wage & 1.40 & 2.75 & 1.15 \\
\hline 6) Real wage/labour productivity (1950=100) & 86.05 & 96.49 & 103.86 \\
\hline 7) Consumer price index/ GDP deflator (1950 =100) & 112.24 & 100.72 & 94.65 \\
\hline 8) Direct tax share of GDP & 2.59 & 9.71 & 13.37 \\
\hline 9) Trade Union Density & 28.02 & 46.19 & 34.31 \\
\hline 10) Expected net replacement rate & 0 & 1.33 & 10.58 \\
\hline 11) Nominal long term interest rate & 4.60 & 4.40 & 8.75 \\
\hline 12) Structural change index based on employment & 5.81 & 2.74 & 1.95 \\
\hline 13) 'World' income growth & 2.24 & 3.54 & 2.52 \\
\hline 14) Fuel Price/ GDP deflator (1950 = 100) & 110.00 & 61.62 & 210.61 \\
\hline
\end{tabular}

Sources: see Appendix. 
Table 2

Econometric Results: Real Wage 1903-2007

(dependent variable $\left.\Delta \log (\mathrm{W} / \mathrm{PC})_{\mathrm{t}}\right)$

\begin{tabular}{|c|c|c|c|c|c|c|}
\hline & (1) & (2) & (3) & (4) & (5) & (6) \\
\hline$\Delta \log \mathrm{Q}_{\mathrm{t}}$ & $\begin{array}{l}0.530 \\
(4.34)\end{array}$ & $\begin{array}{r}0.478 \\
(4.18)\end{array}$ & $\begin{array}{r}0.501 \\
(4.48)\end{array}$ & $\begin{array}{r}0.513 \\
(4.23)\end{array}$ & $\begin{array}{r}0.540 \\
(4.65)\end{array}$ & $\begin{array}{r}0.543 \\
(4.81)\end{array}$ \\
\hline $\log \mathrm{U}_{\mathrm{t}-1}$ & $\begin{array}{r}-0.019 \\
(1.56)\end{array}$ & $\begin{array}{r}-0.019 \\
(3.02)\end{array}$ & $\begin{array}{r}-0.013 \\
(2.01)\end{array}$ & $\begin{array}{r}-0.020 \\
(2.21)\end{array}$ & $\begin{array}{r}-0.016 \\
(1.51)\end{array}$ & $\begin{array}{l}-0.013 \\
(2.35)\end{array}$ \\
\hline $\begin{array}{l}\log (\mathrm{W} / \mathrm{PC})_{\mathrm{t}-1}- \\
\log \mathrm{Q}_{\mathrm{t}-1}\end{array}$ & $\begin{array}{l}-0.114 \\
(2.10)\end{array}$ & $\begin{array}{r}-0.101 \\
(2.18)\end{array}$ & $\begin{array}{l}-0.178 \\
(2.33)\end{array}$ & $\begin{array}{l}-0.183 \\
(2.21)\end{array}$ & & \\
\hline $\log (\mathrm{PC} / \mathrm{PG})_{\mathrm{t}-1}$ & $\begin{array}{r}-0.226 \\
(1.74)\end{array}$ & $\begin{array}{r}-0.172 \\
(1.73)\end{array}$ & $\begin{array}{l}-0.225 \\
(2.03)\end{array}$ & $\begin{array}{l}-0.123 \\
(1.20)\end{array}$ & & \\
\hline $\begin{array}{l}\log (\mathrm{W} / \mathrm{PG})_{\mathrm{t}-1}- \\
\log \mathrm{Q}_{\mathrm{t}-1}\end{array}$ & & & & & $\begin{array}{l}-0.245 \\
(2.86)\end{array}$ & $\begin{array}{l}-0.251 \\
(2.73)\end{array}$ \\
\hline $\begin{array}{l}\text { Dummy 1903- } \\
1941\end{array}$ & $\begin{array}{r}0.023 \\
(1.30)\end{array}$ & $\begin{array}{l}0.026 \\
(1.55)\end{array}$ & $\begin{array}{r}0.029 \\
(1.67)\end{array}$ & $\begin{array}{r}0.076 \\
(1.63)\end{array}$ & $\begin{array}{r}0.053 \\
(1.72)\end{array}$ & $\begin{array}{l}0.050 \\
(2.36)\end{array}$ \\
\hline $\begin{array}{l}\text { Dummy 1942- } \\
1973\end{array}$ & $\begin{array}{r}-0.004 \\
(0.18)\end{array}$ & & & & & \\
\hline World War 1 & & $\begin{array}{r}-0.057 \\
(2.75)\end{array}$ & $\begin{array}{l}-0.058 \\
(2.85)\end{array}$ & $\begin{array}{r}-0.066 \\
(2.60)\end{array}$ & $\begin{array}{r}-0.067 \\
(1.72)\end{array}$ & $\begin{array}{r}-0.066 \\
(3.08)\end{array}$ \\
\hline World War 2 & & $\begin{array}{r}-0.006 \\
(0.38)\end{array}$ & & & & \\
\hline $\begin{array}{l}\text { Log trade union } \\
\text { densityt-1 }\end{array}$ & & & $\begin{array}{r}0.027 \\
(1.56)\end{array}$ & $\begin{array}{r}0.024 \\
(1.39)\end{array}$ & $\begin{array}{l}0.061 \\
(2.03)\end{array}$ & $\begin{array}{r}0.060 \\
(2.23)\end{array}$ \\
\hline $\begin{array}{l}\text { Log adj replace- } \\
\text { ment rate } \\
\text { t-1 }\end{array}$ & & & & $\begin{array}{l}0.004 \\
(1.27)\end{array}$ & & \\
\hline $\begin{array}{l}\text { Log direct tax } \\
\text { share }_{t-1}\end{array}$ & & & & $\begin{array}{r}0.014 \\
(0.91)\end{array}$ & & \\
\hline $\begin{array}{l}\text { 'Wage push' } \\
1974-82\end{array}$ & & & & & $\begin{array}{r}0.035 \\
(1.68)\end{array}$ & $\begin{array}{l}0.031 \\
(2.02)\end{array}$ \\
\hline $\begin{array}{l}\text { 'Accord' } \\
1983-96\end{array}$ & & & & & $\begin{array}{r}0.009 \\
(0.45)\end{array}$ & \\
\hline $\begin{array}{l}\text { 'Ent bargaining' } \\
1997-2007\end{array}$ & & & & & $\begin{array}{l}0.651 \\
(1.78)\end{array}$ & $\begin{array}{l}0.045 \\
(2.61)\end{array}$ \\
\hline Constant & $\begin{array}{l}-0213 \\
(1.65)\end{array}$ & $\begin{array}{r}-0.188 \\
(1.85)\end{array}$ & $\begin{array}{l}-0.323 \\
(2.06)\end{array}$ & $\begin{array}{l}-0.323 \\
(2.06)\end{array}$ & $\begin{array}{l}-0.473 \\
(1.78)\end{array}$ & $\begin{array}{r}-0.486 \\
(2.61)\end{array}$ \\
\hline $\mathrm{R}^{2}$ & 0.213 & 0.264 & 0.304 & 0.304 & 0.345 & 0.343 \\
\hline DW & 1.49 & 1.63 & 1.56 & 1.61 & 1.61 & 1.58 \\
\hline Durbin $\mathrm{H}$ & 7.51 & 3.83 & 6.15 & 4.62 & 4.35 & 3.84 \\
\hline RESET & 1.22 & 0.07 & 0.39 & 2.55 & 2.60 & 2.11 \\
\hline No. Obs. & 105 & 105 & 105 & 105 & 105 & 105 \\
\hline
\end{tabular}

Notes: ' $t$ ' statistics in parentheses computed from robust standard errors. 
Table 3

Econometric Results: Unemployment Rate 1903-2007

(dependent variable: $\log \mathrm{U}_{\mathrm{t}}$ )

\begin{tabular}{|c|c|c|c|c|c|c|}
\hline & (1) & (2) & (3) & (4) & $(5)$ & (6) \\
\hline $\log U_{t-1}$ & $\begin{array}{r}0.657 \\
(10.39)\end{array}$ & $\begin{array}{r}0.621 \\
(10.12)\end{array}$ & $\begin{array}{l}0.578 \\
(9.95)\end{array}$ & $\begin{array}{l}0.610 \\
(9.63)\end{array}$ & $\begin{array}{r}0.687 \\
(11.44)\end{array}$ & $\begin{array}{r}0.715 \\
(18.45)\end{array}$ \\
\hline$\Delta \log \mathrm{Q}_{\mathrm{t}}$ & $\begin{array}{l}-3.480 \\
(3.47)\end{array}$ & $\begin{array}{r}-3.547 \\
(3.88)\end{array}$ & $\begin{array}{r}-3.738 \\
(3.78)\end{array}$ & $\begin{array}{r}-2.361 \\
(1.87)\end{array}$ & $\begin{array}{l}-2.458 \\
(1.92)\end{array}$ & $\begin{array}{r}-3.091 \\
(3.38)\end{array}$ \\
\hline $\begin{array}{l}\log (\mathrm{W} / \mathrm{PC})_{\mathrm{t}-1}- \\
\log \mathrm{Q}_{\mathrm{t}-1}\end{array}$ & $\begin{array}{l}0.798 \\
(1.74)\end{array}$ & $\begin{array}{l}1.047 \\
(3.19)\end{array}$ & $\begin{array}{l}0.989 \\
(2.89)\end{array}$ & $\begin{array}{l}0.887 \\
(2.18)\end{array}$ & $\begin{array}{l}1.011 \\
(3.14)\end{array}$ & \\
\hline $\log (\mathrm{PC} / \mathrm{PG})_{\mathrm{t}-1}$ & $\begin{array}{l}0.307 \\
(0.26)\end{array}$ & $\begin{array}{r}1.140 \\
(1.84)\end{array}$ & $\begin{array}{r}0.951 \\
(1.51)\end{array}$ & $\begin{array}{r}0.693 \\
(0.86)\end{array}$ & $\begin{array}{r}1.004 \\
(1.64)\end{array}$ & \\
\hline $\begin{array}{l}\log (\mathrm{W} / \mathrm{PG})_{\mathrm{t}-1}- \\
\log \mathrm{Q}_{\mathrm{t}-1}\end{array}$ & & & & & & $\begin{array}{r}1.042 \\
(4.42)\end{array}$ \\
\hline $\begin{array}{l}\text { Dummy 1903- } \\
1941\end{array}$ & $\begin{array}{l}0.035 \\
(0.31)\end{array}$ & & & & & \\
\hline $\begin{array}{l}\text { Dummy 1942- } \\
1973\end{array}$ & $\begin{array}{r}-0.428 \\
(3.94)\end{array}$ & $\begin{array}{l}0.486 \\
(5.25)\end{array}$ & $\begin{array}{l}-0.500 \\
(5.69)\end{array}$ & $\begin{array}{r}-0.523 \\
(4.41)\end{array}$ & $\begin{array}{r}-0.120 \\
(0.93)\end{array}$ & \\
\hline World War 1 & & $\begin{array}{l}-0.321 \\
(2.15)\end{array}$ & $\begin{array}{r}-0.251 \\
(1.70)\end{array}$ & $\begin{array}{r}-0.249 \\
(1.50)\end{array}$ & $\begin{array}{l}-0.218 \\
(1.29)\end{array}$ & \\
\hline World War 2 & & $\begin{array}{l}-0.163 \\
(1.00) \\
\end{array}$ & & & & \\
\hline Real interest rate $\mathrm{t}$ & & & $\begin{array}{l}1.306 \\
(2.19)\end{array}$ & $\begin{array}{r}1.117 \\
(1.95)\end{array}$ & $\begin{array}{l}1.147 \\
(2.20)\end{array}$ & $\begin{array}{l}1.455 \\
(2.63) \\
\end{array}$ \\
\hline $\begin{array}{l}\text { Structural change } \\
\text { index }_{\mathrm{t}-1}\end{array}$ & & & $\begin{array}{l}-0.271 \\
(0.28)\end{array}$ & & & \\
\hline $\begin{array}{l}\text { Log real fuel price } \\
\mathrm{t}-1\end{array}$ & & & & $\begin{array}{r}-0.056 \\
(0.80) \\
\end{array}$ & & \\
\hline World growth ${ }_{t}$ & & & & $\begin{array}{r}-1.389 \\
(1.33)\end{array}$ & $\begin{array}{r}-1.052 \\
(1.10)\end{array}$ & \\
\hline $\begin{array}{l}\log U_{t-1} \times \text { dummy } \\
1942-73\end{array}$ & & & & & $\begin{array}{r}-0.420 \\
(3.76)\end{array}$ & $\begin{array}{l}-0.517 \\
(7.59)\end{array}$ \\
\hline Constant & $\begin{array}{l}2.493 \\
(3.33)\end{array}$ & $\begin{array}{r}3.107 \\
(4.02)\end{array}$ & $\begin{array}{r}3.015 \\
(3.83)\end{array}$ & $\begin{array}{r}2.752 \\
(2.91)\end{array}$ & $\begin{array}{l}2.882 \\
(3.82)\end{array}$ & $\begin{array}{r}2.852 \\
(5.2)\end{array}$ \\
\hline $\mathrm{R}^{2}$ & 0.885 & 0.898 & 0.901 & 0.904 & 0.913 & 0.908 \\
\hline DW & 1.84 & 1.87 & 1.82 & 1.91 & 1.97 & 1.98 \\
\hline Durbin $\mathrm{H}$ & 0.34 & 0.22 & 0.58 & 0.02 & 0.06 & 0.05 \\
\hline RESET & 3.04 & 3.18 & 2.50 & 2.59 & 1.31 & 0.55 \\
\hline No. Obs. & 105 & 105 & 105 & 105 & 105 & 105 \\
\hline
\end{tabular}

Notes: ' $t$ ' statistics in parentheses computed from robust standard errors. 
Table 4: Equilibrium Unemployment Rates

\begin{tabular}{|l|r|r|r|}
\hline & $\mathbf{1 9 0 3 - 1 9 4 1}$ & $\mathbf{1 9 4 2 - 1 9 7 3}$ & $\mathbf{1 9 7 4 - 2 0 0 7}$ \\
\hline (1) Average unemployment rate & 7.17 & 1.86 & 6.86 \\
\hline (2) Equilibrium unemployment rate & 6.71 & 1.87 & 5.99 \\
\hline (3) Constant trade union density & 6.71 & 1.57 & 4.91 \\
\hline (4) Constant wage push & 6.71 & 2.36 & 8.13 \\
\hline $\begin{array}{l}\text { (5) Constant trade union density and wage } \\
\text { push }\end{array}$ & 6.71 & 1.98 & 6.66 \\
\hline $\begin{array}{l}\text { (6) Constant real interest rate } \\
\text { (7) Constant productivity growth }\end{array}$ & 6.71 & 1.98 & 6.07 \\
\hline (8) Constant unemployment dynamics & 6.71 & 1.97 & 6.59 \\
\hline $\begin{array}{l}\text { (9) Constant real interest rate and unempt } \\
\text { dynamics and productivity growth }\end{array}$ & 6.71 & 4.88 & 5.99 \\
\hline
\end{tabular}




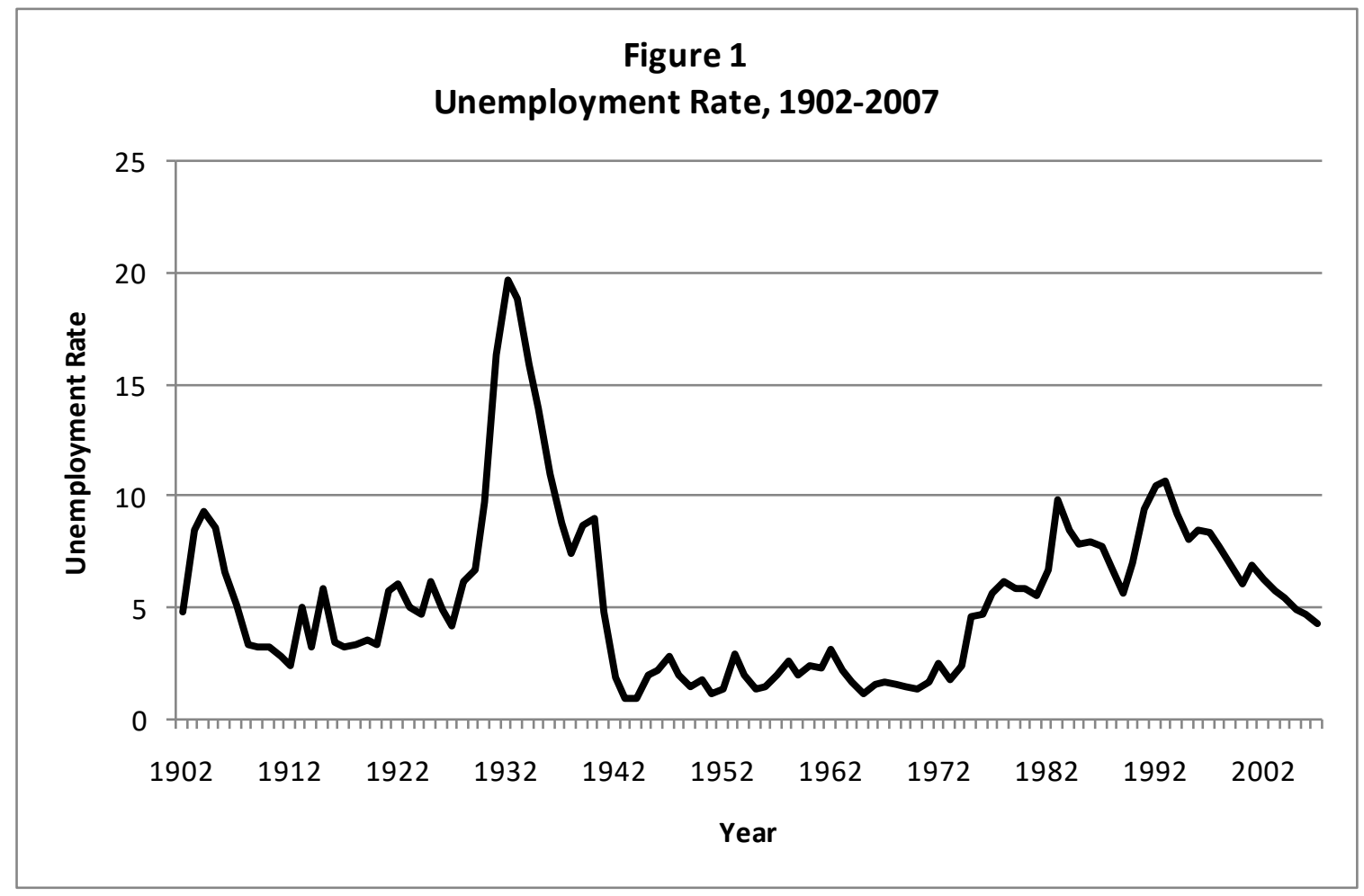

Source: See Data Appendix.

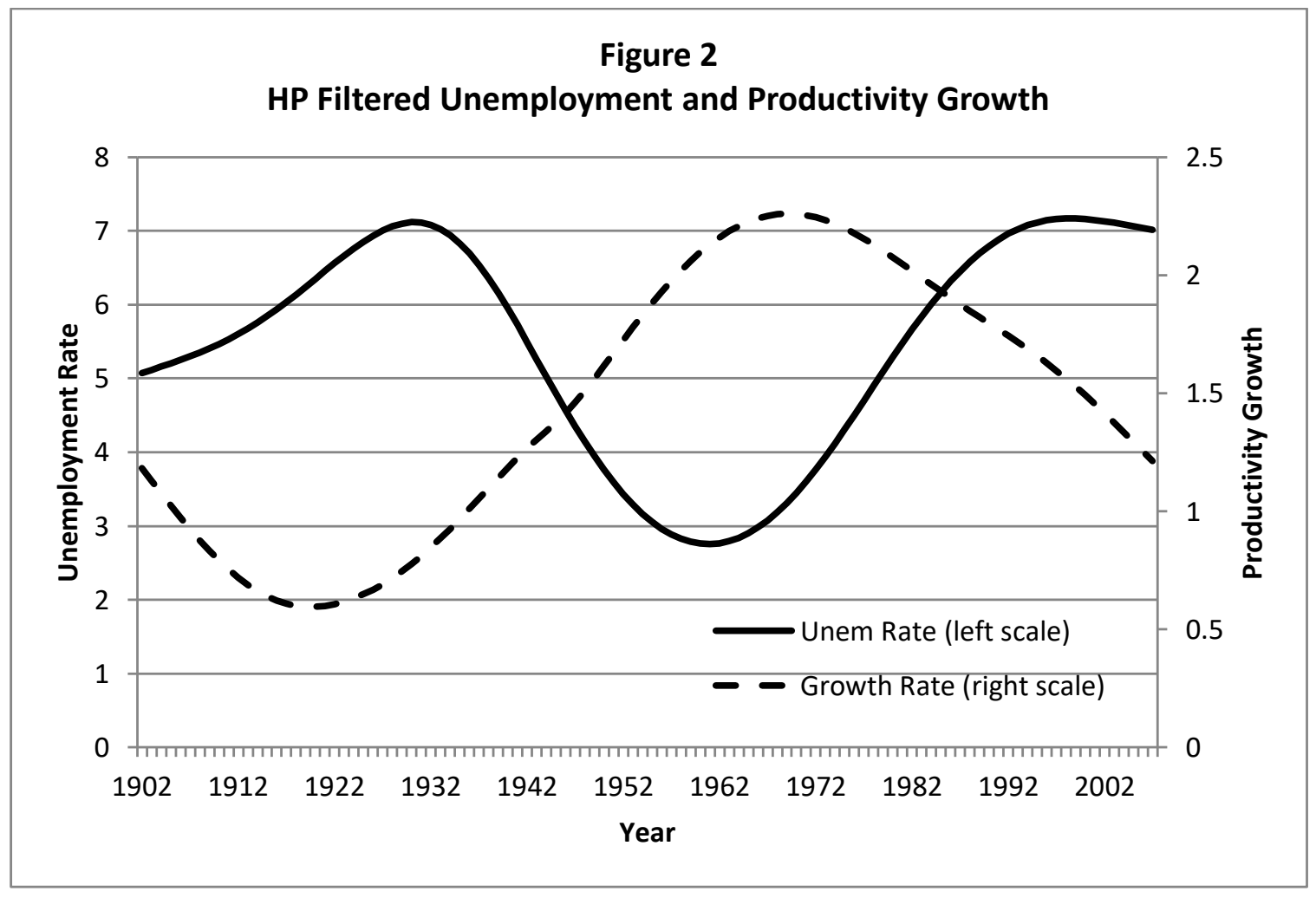

Note: Hodrick Prescott filter, with smoothing parameter 10,000. 


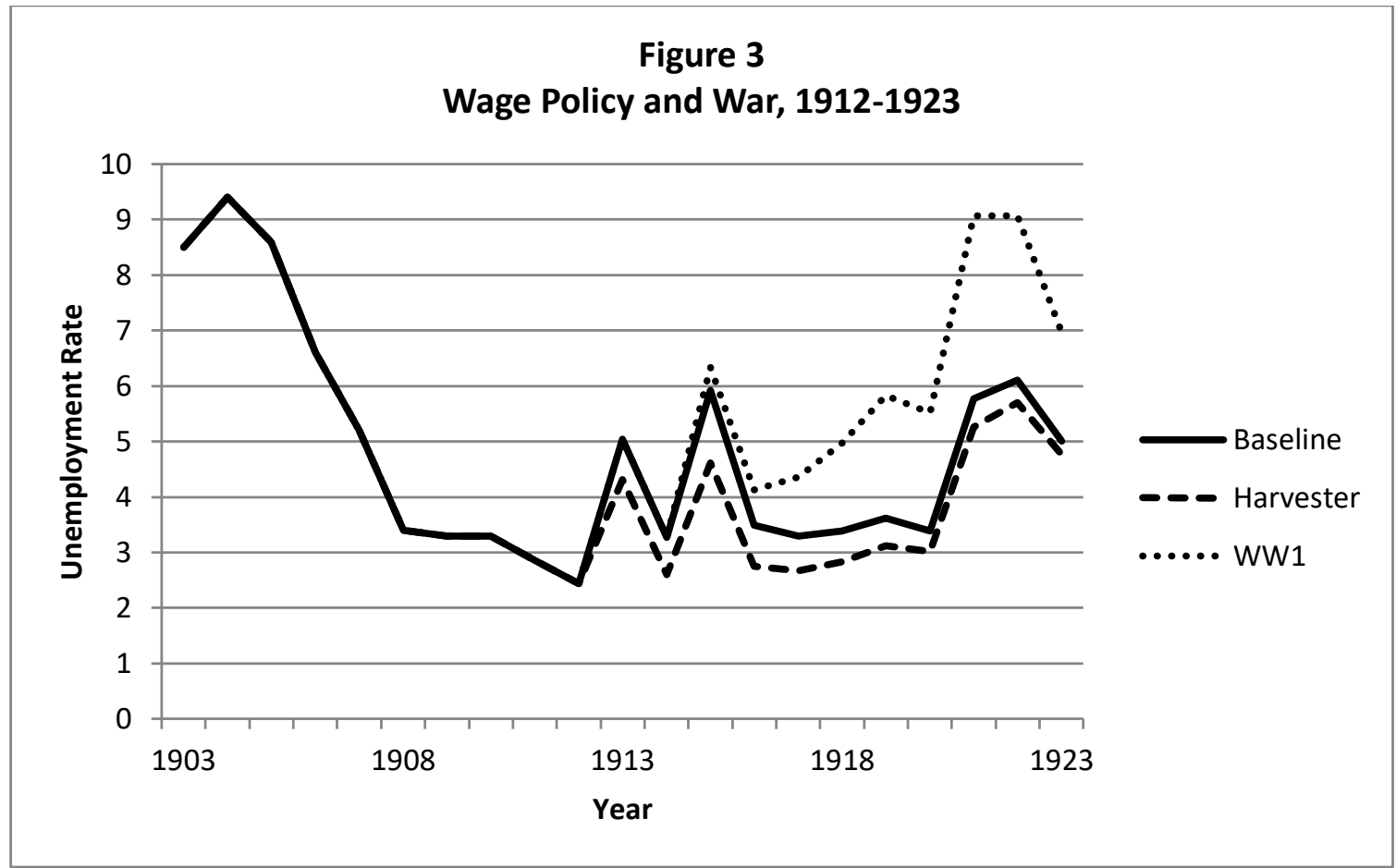

Source: Authors' calculations.

Figure 4

Wage Policy in the Interwar Period

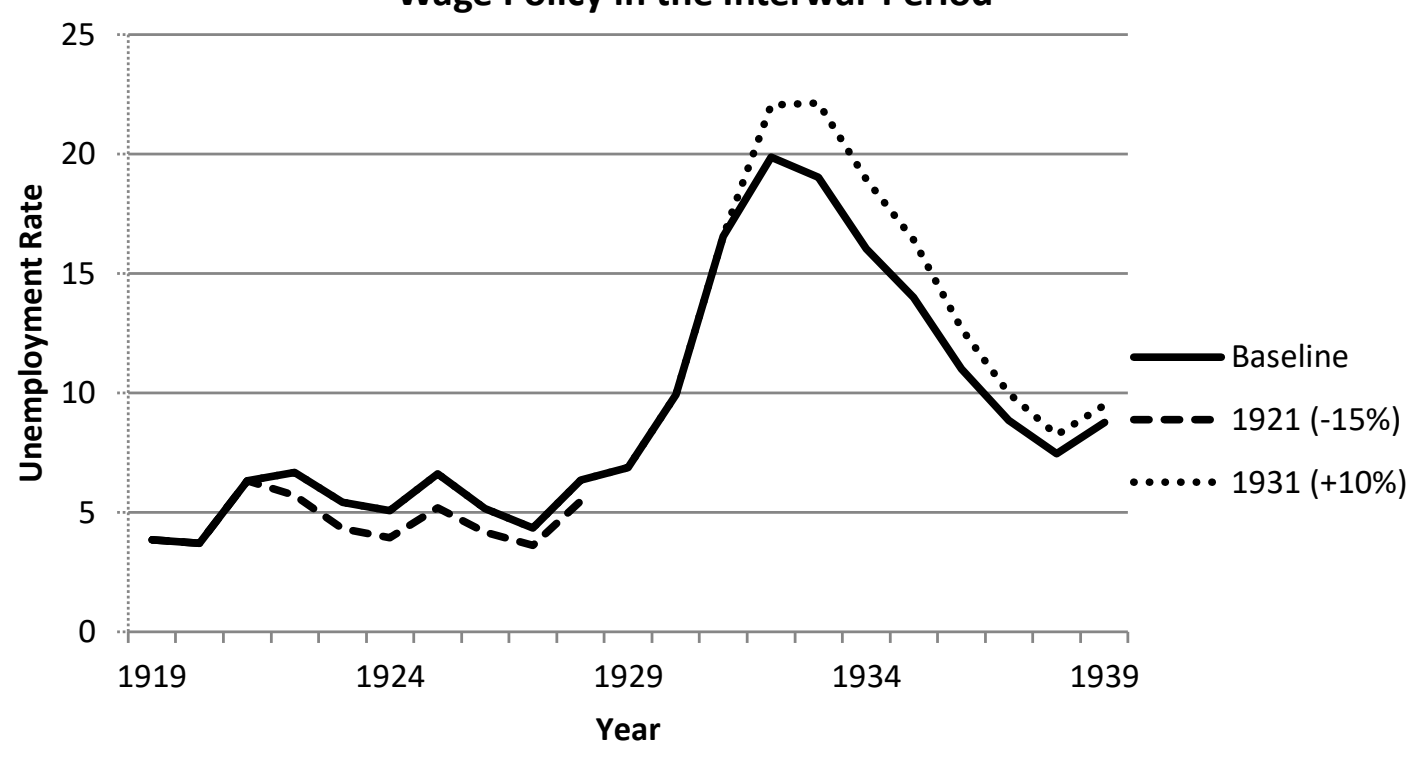

Source: Authors' calculations. 


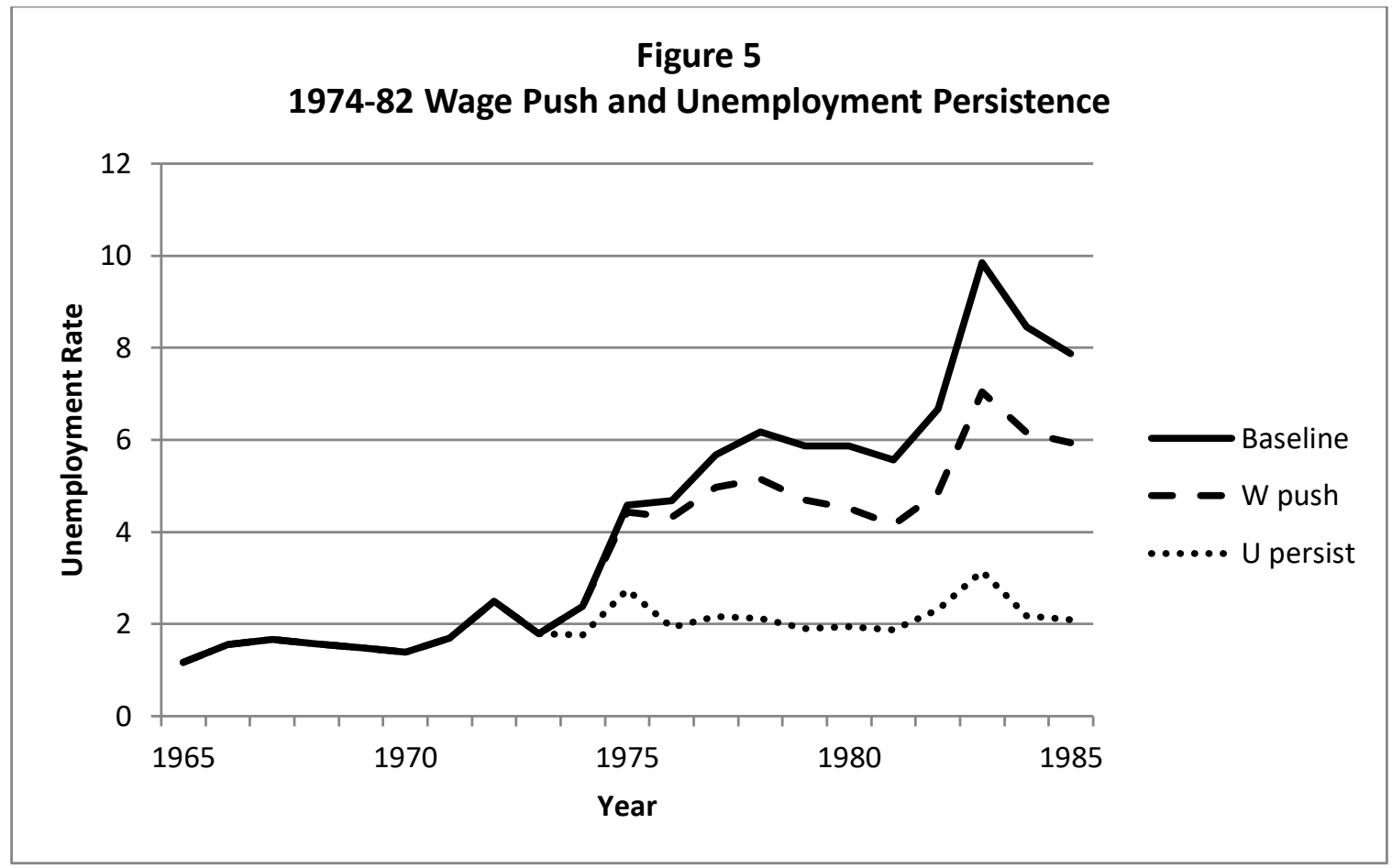

Source: Authors' calculations.

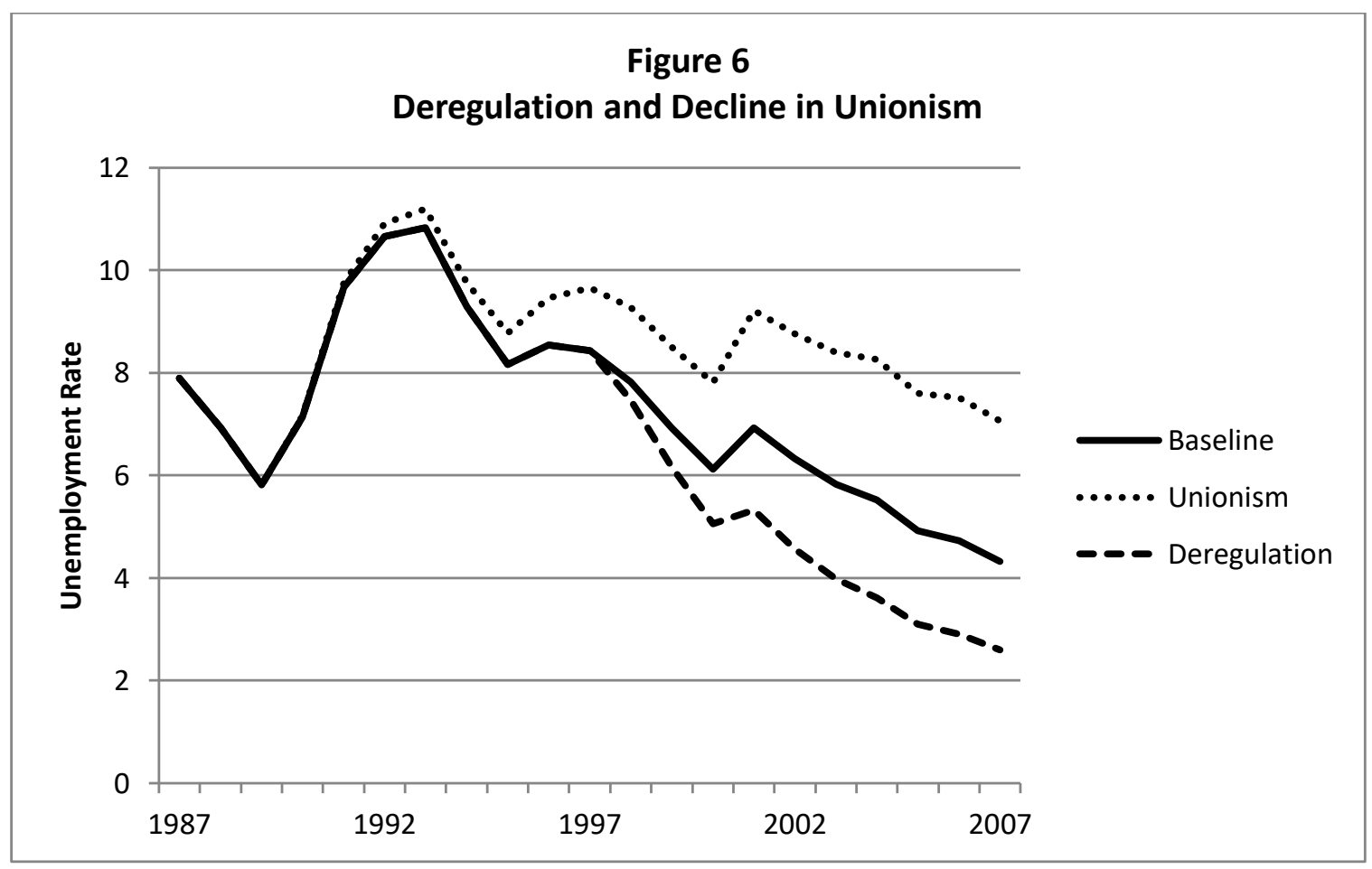

Source: Authors' calculations. 